\title{
Comparative Analyses of the Computer Aided Presentation and Brochure Based Information on the Knowledge of Mothers Regarding the Oral Health Status of Their 0-3 Years Old Children
}

\author{
Bilgisayar Destekli Sunum Şeklindeki Ağız Sağlığı Eğitimi ve Yüz Yüze Broşür \\ Bazlı Bilgilendirmenin 0-3 Yaş Arası Çocuğu Bulunan Annelerin Çocuklarının \\ Ağız ve Diş Sağlığı Hakkında Bilgi Düzeyine Etkisinin Değerlendirilmesi
}

(D) Ömer Faruk Güdük ${ }^{1}$, (1) Tamer Tüzüner ${ }^{1}$, (1) Özgül Baygın ${ }^{1}$, (1) Ayça Kurt², (1) Fatih Korkmaz ${ }^{3}$

${ }^{1}$ Karadeniz Technical University Faculty of Dentistry, Department of Pediatric Dentistry, Trabzon, Turkey

${ }^{2}$ Recep Tayyip Erdoğan University Faculty of Dentistry, Department of Pediatric Dentistry, Rize, Turkey

${ }^{3}$ Karadeniz Technical University Faculty of Dentistry, Department of Prosthodontics, Trabzon, Turkey

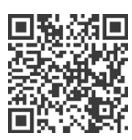

Keywords

Brochure-based information, computer aided presentation, dental health education, preventive dentistry, early childhood caries

\section{Anahtar Kelimeler}

Broşür bazlı bilgilendirme, bilgisayar destekli sunum, dental sağlık eğitimi, koruyucu diş hekimliği, erken çocukluk çağı çürüğü

Received/Geliş Tarihi : 01.02.2021

Accepted/Kabul Tarihi : 03.03.2021

doi:10.4274/meandros.galenos.2021.33254

Address for Correspondence/Yazışma Adresi: Ömer Faruk Güdük, MD,

Karadeniz Technical University Faculty of Dentistry, Department of Pediatric Dentistry,

Trabzon, Turkey

Phone : +90 5302664728

E-mail : ofguduk@gmail.com

ORCID ID: orcid.org/0000-0003-0930-4935

(C) Meandros Medical and Dental Journal, Published by Galenos Publishing House.

This is article distributed under the terms of the Creative Commons Attribution NonCommercial 4.0 International Licence (CC BY-NC 4.0).

\begin{abstract}
Objective: The healthy habits that are created by parents during infancy play an important role in preventing oral and dental health problems, which cause decreased quality of life in children. In this study, the purpose was to evaluate the effectiveness of two different educational methods by providing oral and dental health training with computer-aided presentation (CAP) and Brochure-Based Information (BBI) methods for mothers who have 0-3 age group of children.

Materials and Methods: A total of 90 mothers who had children between the ages of 0-3 participated in this study. Before the training, the participants were asked to fill in the questionnaire forms that contained information on their demographic characteristics and oral hygiene practice knowledge, and the Pre-test (PreT) questionnaire forms that consisted of 12 questions to measure the information levels on oral and dental health of the participants. The participants were asked the same questions again immediately after the training (PostT1), and 3 months later (PostT2). Comparisons were made between the two types of training in terms of PreT, Post, T1 and Post-T2 follow-up periods. Additionally, time-dependent changes were calculated for each group. The chi-square, Mann-Whitney $U$, and McNemar test's were used during the statistical analyses. The $p<0.05$ level was considered significant in all analyses.

Results: In the PreT, no differences were found between the groups ( $p>0.05)$. The CAP group participants were found to be more successful in 03 and 04 in the PostT2 $(p<0.05)$. Moreover, BBI group participants were found to be more successful in the PostT1 for $012(p<0.05)$ and for $02,05,011$, and 012 in the PostT2. In some questions, the time dependent responses also significantly altered the CAP and BBI results. Conclusion: It can be predicted that mothers have a lack of knowledge about the topics of the first dentist visit, early childhood caries and the use of fluoride toothpaste in children. The usage of the BBI method could have more successful outcomes in increasing the knowledge and awareness status of mothers compared to the CAP.
\end{abstract}

Öz

Amaç: Çocuklarda yaşam kalitesinin düşmesine neden olan ağız ve diş sağlığı problemlerinin önlenmesinde ebeveynlerin bebeklik döneminde oluşturdukları sağlıklı alışkanlıkların önemli rolleri vardır. Bu araştırmada, 0-3 yaş grubu çocuğu 
olan annelere bilgisayar destekli sunum (BDS) ve broşür bazlı bilgilendirme (BBB) yöntemleriyle ağız ve diş sağlığı eğitimi verilerek iki farklı eğitim yönteminin etkinliğinin karşılaştırmalı olarak değerlendirilmesi amaçlandı.

Gereç ve Yöntemler: Araştırmaya 0-3 yaş arası çocuğu bulunan 90 anne katıldı. Eğitim öncesinde katılımcılardan içerisinde demografik özellikler ile oral hijyen uygulama bilgilerinin yer aldığı anket formları ve katılımcıların ağız ve diş sağlığı ile ilgili bilgi düzeylerini ölçmeyi amaçlayan 12 sorudan oluşan ön test (ÖT) anket formlarını doldurmaları istendi. Katıımcılara eğitimden hemen sonra (ST1) ve 3 ay sonra (ST2) aynı sorular tekrar soruldu. Her iki eğitim tipi arasında ön test, son test 1 ve son test 2 takip dönemleri açısından gruplar arasında karşılaştırmalar yapıldı. Ayrıca her bir grupta zamana bağlı değişimler hesaplandı. İstatistiksel analizler sırasında kikare, Mann-Whitney U ve McNemar testleri kullanıldı. Tüm analizlerde $p<0,05$ düzeyi anlamlı olarak kabul edildi.

Bulgular: ÖT'de gruplar arasında fark bulunmadı ( $>0,05)$. BDS grubu katılımcılarının ST2 anketindeki 3. ve 4. sorularda daha başarılı oldukları görüldü $(p<0,05)$. Ayrıca BBB grubu katılımcılarının ise ST1'de 12. soruda $(p<0,05)$ ve $S T 2$ de $2,5,11$ ve 12 . sorularda daha başarılı oldukları görüldü.

Sonuç: Annelerin ilk diş hekimi ziyareti, erken çocukluk çürükleri ve çocuklarda florlu diş macunu kullanımı konularında bilgi eksikliğine sahip oldukları tahmin edilebilir. BDS'ye göre BBB yönteminin kullanılması, annelerin bilgi ve farkındalık durumlarını artırmak için daha başarılı sonuçlara sahip olabilir.

\section{Introduction}

The dental caries during the primary teething period is a preventable and reversible process. However, if left untreated, pain, bacteremia risk, growth and developmental disorders, speech disorders, lack of self-confidence and damage to permanent teeth may occur (1).

Researchers reported that the main reason of the poor oral health of children might be inadequate knowledge and attitudes about oral and dental health of parents (especially mothers) and caregivers (2). Programs that promote health in early childhood are needed to be implemented to prevent the formation of dental caries (3). It has been shown in previous studies that there have been significant decreases in the incidence of dental caries among children groups who benefit from preventive programs (4-6). Although it is known that mothers have important roles in the care of her children, and that the main risk factors for many diseases are related with the lifestyle habits, it is considered that the trainings that will be provided especially for parents or caregivers with children between the ages of 0-3 may also reduce the risk of future dental problems (7-10). For this reason, parents and caregivers must have the right knowledge and attitude about oral health from as early periods as possible to give their children healthy oral habits.

When evaluated in terms of educational strategies, it was reported in previous studies that computer or web-assisted implementations (11), brochure-based trainings, face-to-face training and motivational interviews are necessary especially for pediatric age groups to protect and sustain oral health (12).
Researchers evaluate and analyze various training techniques in a comparative manner (12-14). In general, the trainings that are given and repeated may increase oral health, the level of knowledge and the motivation in a much more comfortable way especially in non-hospital settings (13-15).

The hypotheses to be tested in this study are;

1- There may be differences between computeraided presentation (CAP) and brochure-based information (BBI) training methods in terms of each question,

2- The educational methods can be different for each question in the tests to be applied in the pretests and post-tests (PostT) that will be applied in the CAP and $\mathrm{BBI}$ groups.

\section{Materials and Methods}

\section{Study Design}

The present study was conducted in a comparative manner with "Pre-test (PreT) - PostT model". CAP and $\mathrm{BBI}$ training types were evaluated comparatively.

In the present study, the CAP and face-to-face brochure-based oral health trainings were provided to the mothers with children between the ages of 0-3 in an isolated non-clinical/non-hospital setting. The trainings were carried out from August to November 2018. The approval of the Ethics Committee that was required for the study was obtained from the Directorate of the Ethics Committee of Clinical Research of the Faculty of Medicine of the Black Sea Technical University (protocol no: 2018/22; date: 02.03.2018). 


\section{Oral Health Training}

Before the mothers were provided with oral dental health training, informed consent forms was read and signed by the participants in the scope of the study. The questions were compiled from previous studies on this subject in the questionnaire $(7,16,17)$. The form including demographic variables, oral hygiene habits were recorded. Also, the questionnaires consisted of 12 questions was applied on the oral dental health of children (Attachment 1). The timeline training events were given in Figure 1 . The oral-dental health training in the form of CAP was carried out with 7-8 people in groups in 6 sessions in the form of a collective presentation with the help of projector, the $\mathrm{BBI}$ about oral and dental health was completed with sessions held in 5 different days by interviewing the participants face-to-face with the brochures. After the questionnaires were completed, the mothers were given toothbrushes and fluoride-free toothpastes for their children.

\section{Sample size calculation and randomization}

The sampling size was calculated by using $\mathrm{G}$ Power 3.1.9.2 (Universitate Kiel, Germany) programme. The confidence interval $=95 \%$ and the beta error $=0.01$ were used for the calculation based on the study of Hallas et al. (7) and the total number of sampling was determined as 80 . However by considering the potential data losses, the averaged final number was set as 100 . Each group was divided into groups with computer-assisted randomization programme for 50 mothers.

\begin{tabular}{|l|l|}
\hline \multicolumn{2}{|l|}{ Attachment 1. Oral and dental health survey questions } \\
\hline Q1 & The results of oral health problems in children \\
\hline Q2 & Whether the cause of tooth caries bacterial origin \\
\hline Q3 & Primary teeth eruption time \\
\hline Q4 & The first dentist examination time \\
\hline Q5 & Dentist examination frequency \\
\hline Q6 & How healthy milk teeth look \\
\hline Q7 & Early childhood caries risk factors related to nutrition \\
\hline Q8 & Baby's tooth cleaning \\
\hline Q9 & Time of the children alone tooth brushing time \\
\hline Q10 & Fluoride toothpaste use age \\
\hline Q11 & Choosing snacks for kids \\
\hline Q12 & Relationship between nutrition and caries in children \\
\hline
\end{tabular}

\section{Statistical Analysis}

The SPSS (Statistical Package for Social Sciences, SPSS Inc. Chicago, IL, USA) 17.0 Statistical Package Program was used to analyze the data that were obtained in the study. The Kolmogorov-Smirnov, Mann-Whitney U, chi-square and McNemar tests were used for data analysis. The $p<0.05$ was considered to be significant in all analyses.

\section{Results}

A total of 100 participants who were identified as the targets were reached by telephone and informed about the study in the scope of our study. Ninety of those invited to the study participated in the study and 47 mothers were included in the CAP Group and 43 mothers in the BBI Group. The flowing diagram of the study was given in Figure 2.

The distributions of the socio demographic data of the mothers who participated in the study are shown in Table 1. In this context, there was only a statistically significant difference between the educational and occupational status of the mothers between CAP and BBI group $(p<0.001)$, and no significant differences were detected in terms of the number of children between 0-3 years of age, the number of children in other age groups, the genders of the children between 0-3 years of age monthly income of the family, and the ages of the mothers $(p>0.05)$. It was determined that $87.2 \%$ of the mothers in the CAP group were university graduates, $8.5 \%$ were high school graduates; and $44.2 \%$ of the mothers in the $\mathrm{BBI}$ group were university graduates and $25.6 \%$ were high school graduates. In the CAP group, $72.3 \%$ of the participants were employed as teachers, and housewives were the most common occupation group in the BBI group $60.5 \%$ (Table 1). When the oral hygiene habits of the mothers and their children were evaluated, no significant differences were detected between CAP and BBI groups ( $p>0.05$ ) (Table 2).

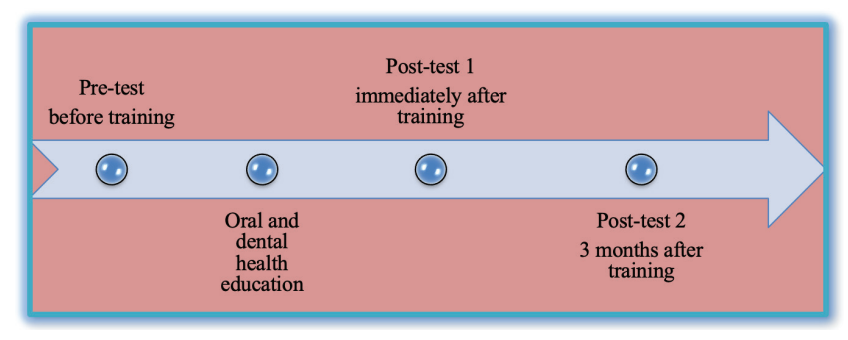

Figure 1. Timeline of study events 


\begin{tabular}{|c|c|c|c|c|}
\hline & CAP $(n=47)$ & BBI $(n=43)$ & Total $(\mathbf{n}=90)$ & ${ }^{1} p,^{2} p,{ }^{3} p$ \\
\hline & $n(\%)$ & $n(\%)$ & $n(\%)$ & \\
\hline \multicolumn{4}{|l|}{ Mother education } & \multirow{5}{*}{${ }^{1} p<0,001$} \\
\hline Primary & $2(4.3 \%)$ & 9 (20.9\%) & $11(12.2 \%)$ & \\
\hline High school & $4(8.5 \%)$ & $11(25.6 \%)$ & $15(16.7 \%)$ & \\
\hline University & $41(87.2 \%)$ & $19(44.2 \%)$ & $60(66.7 \%)$ & \\
\hline Master's degree & $0(0 \%)$ & $4(9.3 \%)$ & $4(4.4 \%)$ & \\
\hline \multicolumn{4}{|l|}{ Number of children 0-3 years } & \multirow{3}{*}{$\begin{array}{l}{ }^{2} p=0.443 \\
p>0.05\end{array}$} \\
\hline 1 child & $43(91.5 \%)$ & 38 (88.4\%) & $81(90 \%)$ & \\
\hline 2 child & $4(8.5 \%)$ & $5(11.6 \%)$ & $9(10 \%)$ & \\
\hline \multicolumn{4}{|l|}{ Number of children in other age } & \multirow{5}{*}{$\begin{array}{l}{ }^{2} p=0.790 \\
p>0.05\end{array}$} \\
\hline 0 & $23(48.9 \%)$ & $22(51.2 \%)$ & $45(50 \%)$ & \\
\hline 1 child & $15(31.9 \%)$ & $11(25.6 \%)$ & $26(28.9 \%)$ & \\
\hline 2 child & 7 (14.9\%) & $9(20.9 \%)$ & $16(17.89 \%)$ & \\
\hline 3 child & $2(4.3 \%)$ & $1(2.3 \%)$ & $3(3.3 \%)$ & \\
\hline \multicolumn{4}{|l|}{ Child gender } & \multirow{7}{*}{$\begin{array}{l}{ }^{2} p=0.469 \\
p>0.05\end{array}$} \\
\hline 1 girl & $21(44.7 \%)$ & $18(41.9 \%)$ & $39(43.3 \%)$ & \\
\hline 1 boy & $22(46.8 \%)$ & $20(46.5 \%)$ & $42(46.7 \%)$ & \\
\hline 2 girls & $2(4.3 \%)$ & $1(2.3 \%)$ & $3(3.3 \%)$ & \\
\hline 2 boys & $0(0 \%)$ & $1(2.3 \%)$ & $1(1.1 \%)$ & \\
\hline 1 boy ande $1 \mathrm{girl}$ & $0(0 \%)$ & $2(4.7 \%)$ & $2(2.2 \%)$ & \\
\hline Unknown answer & $2(4.3 \%)$ & $1(2.3 \%)$ & $3(3.3 \%)$ & \\
\hline \multicolumn{4}{|l|}{ Average family monthly income } & \multirow{4}{*}{$\begin{array}{l}{ }^{2} p=0.060 \\
p>0.05\end{array}$} \\
\hline $0-2000 \mathrm{TL}$ & $3(6.4 \%)$ & $3(7.0 \%)$ & $6(6.7 \%)$ & \\
\hline 2000-5000 TL & $14(29.8 \%)$ & $23(53.5 \%)$ & $37(41.1 \%)$ & \\
\hline$\geq 5000 \mathrm{TL}$ & $30(63.8 \%)$ & $17(39.5 \%)$ & $47(52.2 \%)$ & \\
\hline \multicolumn{4}{|l|}{ Mother occupation } & \multirow{16}{*}{${ }^{1} p<0.001$} \\
\hline Teacher & $34(72.3 \%)$ & $4(9.3 \%)$ & $38(42.2 \%)$ & \\
\hline Computer programmer & $1(2.1 \%)$ & $0(0 \%)$ & $1(1.1 \%)$ & \\
\hline Doctor & $1(2.1 \%)$ & $2(4.7 \%)$ & $3(3.3 \%)$ & \\
\hline Banker & $1(2.1 \%)$ & $1(2.3 \%)$ & $2(2.2 \%)$ & \\
\hline Medical secretary & $1(2.1 \%)$ & $1(2.3 \%)$ & $2(2.2 \%)$ & \\
\hline Lawyer & $1(2.1 \%)$ & $0(0 \%)$ & $1(1.1 \%)$ & \\
\hline Teknician & $0(0 \%)$ & $1(2.3 \%)$ & $1(1.1 \%)$ & \\
\hline Nurse & $0(0 \%)$ & $2(4.7 \%)$ & $2(2.2 \%)$ & \\
\hline Housewife & $8(17 \%)$ & $26(60.5 \%)$ & $34(37.8 \%)$ & \\
\hline Student & $0(0 \%)$ & $1(2.3 \%)$ & $1(1.1 \%)$ & \\
\hline Architect & $0(0 \%)$ & $1(2.3 \%)$ & $1(1.1 \%)$ & \\
\hline Business & $0(0 \%)$ & $1(2.3 \%)$ & $1(1.1 \%)$ & \\
\hline Chemist & $0(0 \%)$ & $1(2.3 \%)$ & $1(1.1 \%)$ & \\
\hline Operation responsible & $0(0 \%)$ & $1(2.3 \%)$ & $1(1.1 \%)$ & \\
\hline Akademician & $0(0 \%)$ & $1(2.3 \%)$ & $1(1.1 \%)$ & \\
\hline Mean age (minimum - maximum) & $33.06 \pm 4.204(25-46)$ & $32.23 \pm 4.529(25-43)$ & & ${ }^{3} p=0.153 p>0.05$ \\
\hline
\end{tabular}


The comparison between the groups based on the correct answers given by the participants in both groups to the questions in the questionnaire in the PreT, PostT1 and PostT2 is shown in Table 3. In this respect, no statistically significant differences were detected between the CAP and $\mathrm{BBI}$ groups in 12 questions answered in the PreT questionnaire ( $p>0.05)$, and it was determined that the BBI group was more successful in the Q12 $(p=0.030)$ in the PostT1, and the BBI group was more successful in the in the Q2 ( $p=0.021), Q 5(p=0.044), Q 11(p=0.042)$ and Q12 ( $p=0.048)$ in the PostT2 questionnaire; and the

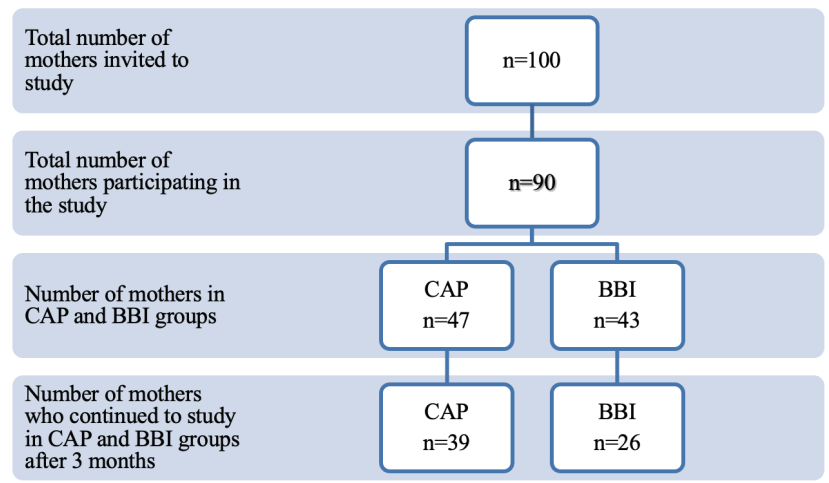

Figure 2. Distribution of the number of participants at baseline and follow-up periods

CAP: Computer aided presentation, BBI: Brochure based Informatio
CAP group was more successful in the $Q 3(p=0.035)$ and in the Q4 $(p=0.048)$ in the PostT2 questionnaire.

The correct answer numbers and rates of the mothers who participated in the study in CAP and BBI Groups are shown in Table 4. In this respect, in the CAP Group, "dental caries are bacterial (Q2)" and "the time when children started to brush their teeth (Q9)" was the questions that were most correctly answered $(83 \%)$, and it was determined that the rate of the correct answers given to the question was the least with a rate of $17 \%$ in the question "the age of using fluoride toothpaste (Q10)"; however, it was also determined that the rate of this question increased at a significant level after the training. When the questionbased intra-group changes were examined in the CAP Group, it was determined that there were statistically significant increases in the PreT and PostT1 in the Q1 $(p<0.001), Q 3(p=0.008), Q 4(p<0.001), Q 5(p=0.027)$, Q6 ( $p=0.006), Q 7(p<0.001), Q 10(p<0.001)$ and Q11 $(p=0.003)$; and between the PreT and PostT2 in the Q7 ( $p=0.012), Q 10(p=0.021)$ and Q12 ( $p=0.039)$; and there was a decrease at a statistically significant level in the Q1 $(p=0.016)$ and Q4 $(p=0.022)$ between the PostT1 and PostT2 questionnaires.

In the BBI group, "dental caries are bacterial (Q2)" was the most correctly answered question with a rate

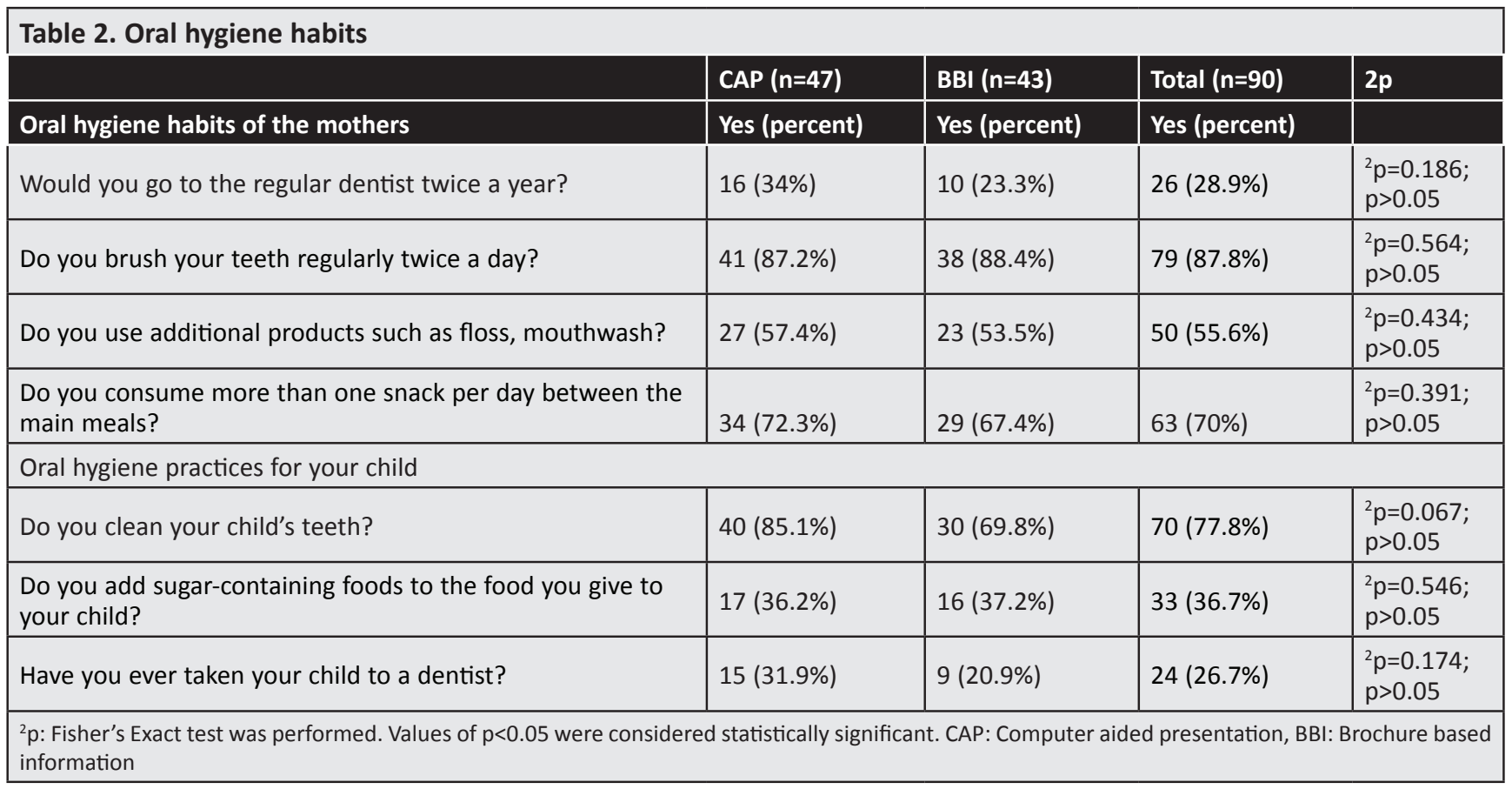




\begin{tabular}{|c|c|c|c|}
\hline & PreT & PostT1 & PostT2 \\
\hline Q1.'The results of oral health problems in children' & $p>0.05$ & $p>0.05$ & $\mathrm{p}>0.05$ \\
\hline Q2.'Whether the cause of tooth caries bacterial origin' & $p>0.05$ & $p>0.05$ & ${ }^{2} p=0.021 ; p<0.05$ \\
\hline Q3.'Primary teeth eruption time' & $p>0.05$ & $p>0.05$ & ${ }^{2} p=0.035 ; p<0.05$ \\
\hline Q4.'The first dentist examination time' & $p>0.05$ & $p>0.05$ & ${ }^{2} p=0.048 ; p<0.05$ \\
\hline Q5.'Dentist examination frequency' & $p>0.05$ & $p>0.05$ & ${ }^{2} p=0.044 ; p<0.05$ \\
\hline Q6.'How healthy milk teeth look' & $p>0.05$ & $p>0.05$ & $p>0.05$ \\
\hline Q7. 'Early childhood caries risk factors related to nutrition' & $p>0.05$ & $p>0.05$ & $p>0.05$ \\
\hline Q8.'Baby's tooth cleaning' & $p>0.05$ & $p>0.05$ & $p>0.05$ \\
\hline Q9. 'Time of the children alone tooth brushing time' & $p>0.05$ & $p>0.05$ & $p>0.05$ \\
\hline Q10.'Fluoride toothpaste use age' & $p>0.05$ & $p>0.05$ & $p>0.05$ \\
\hline Q11.'Choosing snacks for kids' & $p>0.05$ & $p>0.05$ & ${ }^{2} p=0.042 ; p<0.05$ \\
\hline Q12.'Relationship between nutrition and caries in children' & $p>0.05$ & ${ }^{2} p=0.030 ; p<0.05$ & ${ }^{2} p=0.048 ; p<0.05$ \\
\hline
\end{tabular}

of $88 \%$. The least correctly answered question was the "early childhood caries (ECC) risk factors (Q7)" with a rate of 16\%; however, it was also determined that it increased at a significant level right after the training. It was determined that the number of the correct answers given to all questions increased in the PostT1 questionnaire compared to the PreT questionnaire. When the PreT and PostT1 questionnaire answers were compared, it was determined that there were significant improvements in 8 questions. When the time-dependent variations were compared between the questionnaires in the $\mathrm{BBI}$ group, statistically significant increases were detected between the PreT and PostT1 in the Q1 $(p<0.001), Q 4(p<0.001), Q 5$ $(p<0.001), Q 6(p=0.013), Q 7(p<0.001), Q 10(p<0.001)$, Q11 $(p<0.001)$ and Q12 ( $p=0.002)$; and between the PreT and PostT2 in the Q1 ( $p=0.016), Q 6(p=0.006)$, Q7 ( $p=0.012)$ and Q12 ( $p=0.006)$; and there were decreases at significant levels between the PostT1 and PostT2 in the Q4 ( $p=0.008), Q 7(p=0.039)$ and Q10 ( $p<0.001)$ (Table 4).

Sixty-five of the 90 mothers who participated in the study completed the study by also filling out the PostT2 questionnaire, 39 of these participants were CAP group and 26 were BBI group participants. To determine whether the attendance in our study had an effect on the outcomes of the study, intra-group and intergroup comparisons were made for the data of continuing $(n=65)$ and non-continuing $(n=25)$ mothers. No significant differences were detected between the participants who continued and who did not continue (missing) in any of the items in which the demographic data and oral hygiene habits were questioned in the intra-group comparisons. When the questions in the questionnaires were evaluated, it was determined that there were significant differences in terms of the continuing mothers only in the $5^{\text {th }}$ question in the PreT questionnaire in the CAP group $(p=0,028)$, and in the $6^{\text {th }}$ question $(p=0.029)$ in the PostT1 questionnaire in the BBI group.

As a result of the sensitivity analysis made by substituting the missing data in the responses of the participants who did not continue (missing) the study in the pre-training questionnaires with the answers given in the PostT2 questionnaire, which was carried out 3 months after the training, it was determined that there were no statistically significant in any of the 12 questions in the PostT2 questionnaire between the CAP and BBI groups ( $p>0.05)$

\section{Discussion}

As a result of our study, it was determined in the inter-group and intra-group comparisons that there were no significant differences in all the questions; for this reason, the two hypotheses that were tested were not 


\begin{tabular}{|c|c|c|c|c|c|c|c|c|c|c|c|c|}
\hline & CAP & BBI & CAP & BBI & CAP & BBI & CAP & BBI & CAP & BBI & CAP & $3 B I$ \\
\hline & $n=47$ & $n=43$ & $n=47$ & $n=43$ & $n=39$ & $n=26$ & ${ }^{4} p$ & ${ }^{4} p$ & ${ }^{4} p$ & ${ }^{4} p$ & ${ }^{4} p$ & ${ }^{4} p$ \\
\hline \multicolumn{13}{|l|}{ Questions } \\
\hline $\begin{array}{l}\text { Q1. The results } \\
\text { of oral health } \\
\text { problems in } \\
\text { children }\end{array}$ & $\begin{array}{l}31 \\
(66 \%)\end{array}$ & $\begin{array}{l}24 \\
(56 \%)\end{array}$ & $\begin{array}{l}46 \\
(98 \%)\end{array}$ & \begin{tabular}{|l}
39 \\
$(91 \%)$
\end{tabular} & $\begin{array}{l}31 \\
(79 \%)\end{array}$ & $\begin{array}{l}22 \\
(85 \%)\end{array}$ & ${ }^{4} p<0.001$ & ${ }^{4} p<0.001$ & $\begin{array}{l}{ }^{4} p=0.065 \\
p>0.05\end{array}$ & $\begin{array}{l}{ }^{4} p=0.016 \\
p<0.05\end{array}$ & $\begin{array}{l}{ }^{4} p=0.016 \\
p<0.05\end{array}$ & $\begin{array}{l}{ }^{4} p=0.625 \\
p>0.05\end{array}$ \\
\hline $\begin{array}{l}\text { Q2. Whether the } \\
\text { cause of tooth } \\
\text { caries bacterial } \\
\text { origin }\end{array}$ & $\begin{array}{l}39 \\
(83 \%)\end{array}$ & $\begin{array}{l}38 \\
(88 \%)\end{array}$ & \begin{tabular}{|l}
44 \\
$(94 \%)$
\end{tabular} & \begin{tabular}{|l}
40 \\
$(93 \%)$
\end{tabular} & $\begin{array}{l}33 \\
(85 \%)\end{array}$ & $\begin{array}{l}25 \\
(96 \%)\end{array}$ & $\begin{array}{l}{ }^{4} p=0.18 \\
p>0.05\end{array}$ & $\begin{array}{l}{ }^{4} p=0.727 \\
p>0.05\end{array}$ & $\begin{array}{l}{ }^{4} p=0.754 \\
p>0.05\end{array}$ & $\begin{array}{l}{ }^{4} p=0.625 \\
p>0.05\end{array}$ & $\begin{array}{l}{ }^{4} p=0.219 \\
p>0.05\end{array}$ & $\begin{array}{l}{ }^{4} p=1.00 \\
p>0.05\end{array}$ \\
\hline $\begin{array}{l}\text { Q5. Dentist } \\
\text { examination } \\
\text { frequency }\end{array}$ & $\begin{array}{l}31 \\
(66 \%)\end{array}$ & $\begin{array}{l}24 \\
(56 \%)\end{array}$ & $\begin{array}{l}42 \\
(89 \%)\end{array}$ & $\begin{array}{l}41 \\
(95 \%)\end{array}$ & $\begin{array}{l}30 \\
(77 \%)\end{array}$ & $\begin{array}{l}22 \\
(85 \%)\end{array}$ & $\begin{array}{l}{ }^{4} p=0.027 \\
p<0.05\end{array}$ & ${ }^{4} p<0.001$ & $\begin{array}{l}{ }^{4} p=1.00 \\
p>0.05\end{array}$ & $\begin{array}{l}{ }^{4} p=0.109 \\
p>0.05\end{array}$ & $\begin{array}{l}{ }^{4} p=0.227 \\
p>0.05\end{array}$ & $\begin{array}{l}{ }^{4} p=0.125 \\
p>0.05\end{array}$ \\
\hline $\begin{array}{l}\text { Q6. How healthy } \\
\text { milk teeth look }\end{array}$ & $\begin{array}{l}31 \\
(66 \%)\end{array}$ & $\begin{array}{l}24 \\
(56 \%)\end{array}$ & $\begin{array}{l}41 \\
(87 \%)\end{array}$ & $\begin{array}{l}34 \\
(81 \%) \\
n=42\end{array}$ & $\begin{array}{l}31 \\
(79 \%)\end{array}$ & $\begin{array}{l}22 \\
(85 \%)\end{array}$ & $\begin{array}{l}{ }^{4} p=0.006 \\
p<0.05\end{array}$ & $\begin{array}{l}{ }^{4} p=0.013 \\
p<0.05\end{array}$ & $\begin{array}{l}{ }^{4} p=0.146 \\
p>0.05\end{array}$ & $\begin{array}{l}{ }^{4} p=0.006 \\
p<0.05\end{array}$ & $\begin{array}{l}{ }^{4} p=0.375 \\
p>0.05\end{array}$ & $\begin{array}{l}{ }^{4} p=0.688 \\
p>0.05\end{array}$ \\
\hline $\begin{array}{l}\text { Q7. ECC risk } \\
\text { factors related to } \\
\text { nutrition' }\end{array}$ & $\begin{array}{l}13 \\
(28 \%)\end{array}$ & $\begin{array}{l}7 \\
(16 \%)\end{array}$ & $\begin{array}{l}36 \\
(76 \%)\end{array}$ & \begin{tabular}{|l}
35 \\
$(81 \%)$
\end{tabular} & $\begin{array}{l}23 \\
(59 \%)\end{array}$ & $\begin{array}{l}14 \\
(54 \%)\end{array}$ & ${ }^{4} p<0.001$ & ${ }^{4} p<0.001$ & $\begin{array}{l}{ }^{4} p=0.012 \\
p<0.05\end{array}$ & $\begin{array}{l}{ }^{4} p=0.012 \\
p<0.05\end{array}$ & $\begin{array}{l}{ }^{4} p=0.302 \\
p>0.05\end{array}$ & $\begin{array}{l}{ }^{4} p=0.039 \\
p<0.05\end{array}$ \\
\hline $\begin{array}{l}\text { Q11. Choosing } \\
\text { snacks for kids }\end{array}$ & \begin{tabular}{|l|}
30 \\
$(64 \%)$
\end{tabular} & $\begin{array}{l}24 \\
(56 \%)\end{array}$ & $\begin{array}{l}41 \\
(87 \%)\end{array}$ & \begin{tabular}{|l}
91 \\
$(39 \%)$
\end{tabular} & $\begin{array}{l}28 \\
(72 \%)\end{array}$ & \begin{tabular}{|l|}
21 \\
$(81 \%)$
\end{tabular} & $\begin{array}{l}{ }^{4} p=0.003 \\
p<0.05\end{array}$ & ${ }^{4} p<0.001$ & $\begin{array}{l}{ }^{4} p=0.344 \\
p>0.05\end{array}$ & $\begin{array}{l}{ }^{4} p=0.039 \\
p>0.05\end{array}$ & $\begin{array}{l}{ }^{4} p=0.109 \\
p>0.05\end{array}$ & $\begin{array}{l}{ }^{4} p=0.375 \\
p>0.05\end{array}$ \\
\hline $\begin{array}{l}\text { Q12. Relationship } \\
\text { between nutrition } \\
\text { and caries in } \\
\text { children }\end{array}$ & $\begin{array}{l}33 \\
(68 \%)\end{array}$ & $\begin{array}{l}28 \\
(65 \%)\end{array}$ & $\begin{array}{l}36 \\
(76 \%)\end{array}$ & $\begin{array}{l}40 \\
(93 \%)\end{array}$ & $\begin{array}{l}34 \\
(87 \%)\end{array}$ & $\begin{array}{l}24 \\
(92 \%)\end{array}$ & $\begin{array}{l}{ }^{4} p=0.481 \\
p>0.05\end{array}$ & $\begin{array}{l}{ }^{4} p=0.002 \\
p<0.05\end{array}$ & $\begin{array}{l}{ }^{4} p=0.039 \\
p<0.05\end{array}$ & $\begin{array}{l}{ }^{4} p=0.006 \\
p<0.05\end{array}$ & $\begin{array}{l}{ }^{4} p=0.267 \\
p>0.05\end{array}$ & $\begin{array}{l}{ }^{4} p=1.00 \\
p>0.05\end{array}$ \\
\hline
\end{tabular}

accepted for all questions, and were partially accepted.

Our study was conducted with a $72 \%$ participation rate in the 3-month follow-up period with a total of 90 mothers in two groups. Although the number of the participants was determined to be 100 in the sampling size calculation (7), 90 mothers were able to participate in the study, and in addition to the insufficient interest in the training through mass media, the fact that the society does not pay adequate attention for this issue may suggest that it is effective for mothers to engage in the caretaking of their children, and not be able to devote time to train them because of the criteria of having children between the ages of 0-3. A total of 65 of the 90 mothers who participated in 
the study completed the study by filling in the PostT2 questionnaire in the $3^{\text {rd }}$ month after the training.

In a similar study that was conducted in Iran, it was determined that the rate of participants who completed the study at the end of 3-month followup period was $80 \%$ (18), and in a study that was conducted by Hoeft et al. (19), they reached a followup rate of $75 \%$ at the end of 3 months. In the study that was conducted by Hallas et al. (7), only 10 of the 94 mothers participated in the continuation of the study. For this reason, it may be considered that the $72 \%$ participation rate in the study is acceptable. When the socio-demographic characteristics of the two groups were compared, it was determined that there is only a statistically significant difference between the mothers' educational status $(p<0.001)$ and their professions $(p<0.001)$; this and the lack of significant differences between the oral hygiene practices of the parents and their children and the answers given by them to initial questionnaires show that the participants of the two groups have very similar characteristics.

In the present study, the purpose was to compare only the effectiveness of the methods by using the same information and the same visuals in the trainings given to both groups. The participants in the $\mathrm{BBI}$ group in which the face-to-face training model was applied were trained with brochures during the training; however, these brochures were not given to the participants considering that the $3^{\text {rd }}$ month checkups would be carried out by e-mail and telephone, and not to create bias when comparing the sustainability of the information acquired in education. In a study that evaluated the oral health training conducted by Makvandi et al. (18), the mothers in the intervention group were informed by a booklet, and this booklet was given to the mothers to re-read them at an appropriate time and remember the messages given. In this study, different from the present study of ours, it was observed that there was only one intervention group. In the scope of our study, the values in the three periods were compared by conducting a questionnaire before, immediately after the training and 3 months after the training to determine whether the changes in the level of knowledge were sustainable. However, there are also researchers who recommend longerterm studies $(7,20)$.
According to the answers given to the questionnaires by CAP and BBI group participants, no statistically significant differences were detected in any question in the PreT questionnaire $(p>0.05)$, and both groups were similar in terms of the answers to the questions and in terms of the initial knowledge levels. It was determined that BBI group participants gave more accurate answers at significant levels to the in the Q12 $(p=0.030)$ in the PostT1 questionnaire, and in the Q2 $(p=0.021), Q 5$ $(p=0.044), Q 11(p=0.042)$ and Q12 $(p=0.048 ; p<0.05)$ in the PostT2 questionnaire; and CAP group participants gave more accurate answers at significant levels in the Q3 $(p=0.035)$ and Q4 $(p=0.048)$ in the PostT2 questionnaire. In the light of these results, it may be considered that there was a significant increase in the knowledge levels of the participants in the $\mathrm{BBI}$ group than of the participants of the CAP group; and that the training with $\mathrm{BBI}$ was more successful. Meanwhile, considering the higher educational status of the CAP group participants $(p<0.001)$, it can be predicted that the participants' educational status was not effective as a result of our study.

In a study conducted by Hallas et al. (7), before the oral health training, the mothers were asked "do you think fluoride is safe and it helps prevent dental caries as your baby grows?", and $71.6 \%$ of the mothers said "yes"; and they were also asked "Do you think that dentist examination is important when your baby reached the age of 1 , and $89.2 \%$ of the mothers said "yes" at a rate of $89.2 \%$. When Weber and Gasparoni (21) questioned whether mothers who had children between 12-49 months used fluoride toothpaste for their children, it was observed that this rate increased after the training, and $30 \%$ of the participants initially answered "yes".

It was reported in another study that was conducted in Latin population that the correct answer rate was initially lower when the relationship between the development of caries and nutrition was questioned (21). In our study, the questions that were asked to the participants before the training were given a lower percentage about the question when the first dentist examination should be (Q4), ECC risk factors (Q7), and fluoride toothpaste use (Q10). It is observed that the correct answer rates given to these questions increased at significant levels compared to the initial values after the training in both the CAP and BBI groups. 
The absence of a control group in the study might be considered as a limitation; however, the evaluation of the time-dependent changes in each group, in other words, the Quasi-experimental design of the study eliminated the need for a control group. Although the loss of participants in the follow-up periods appeared before us as another limitation, when we compared the continuing and non-continuing (missing) participants, no differences that could change the results of the study could be detected for each group. However, increasing the continuing participant rates in future studies will be useful.

\section{Conclusion}

It can be foreseen that both methods will increase the level of knowledge, but awareness may be higher due to the use of $\mathrm{BBI}$ in oral and dental health training that will be given to mothers. In addition, it was determined that missing knowledge was less in the time of the first dentist examination in children (Q4), the nutritional risk factors of the ECC (Q7), fluoride toothpaste use (Q10) compared to the other questions, and the long-term persistence of the knowledge learnt was less compared to the other questions. For this reason, it may be considered useful to allocate more time to these topics in the studies and social education programs that will be planned in the future.

\section{Acknowledgments}

Technical support was provided to this research by the Eastern Black Sea development agency. We would like to thank the General Secretary of the Eastern Black Sea Development Agency, Onur Adıyaman, for his support in the realization of the participant trainings in this study.

\section{Ethics}

Ethics Committee Approval: The approval of the Ethics Committee that was required for the study was obtained from the Directorate of the Ethics Committee of Clinical Research of the Faculty of Medicine of the Karadeniz Technical University (protocol no: 2018/22; date: 02.03.2018).

Informed Consent: Before the mothers were provided with oral dental health training, informed consent forms was read and signed by the participants in the scope of the study.

Peer-review: Externally and internally peerreviewed.

\section{Authorship Contributions}

Surgical and Medical Practices: Ö.F.G., T.T., Concept: Ö.F.G., T.T., F.K., Design: Ö.F.G., T.T., Ö.B., F.K., Data Collection or Processing: Ö.F.G., A.K., Analysis or Interpretation: Ö.F.G., T.T., Ö.B., Literature Search: Ö.F.G., T.T., A.K., Writing: Ö.F.G., T.T.

Conflict of Interest: No conflict of interest was declared by the authors.

Financial Disclosure: Technical support was provided to this research by the Eastern Black Sea Development Agency (DOKA).

\section{References}

1. Kagihara LE, Niederhauser VP, Stark M. Assessment, management, and prevention of early childhood caries. J Am Acad Nurse Pract 2009; 21: 1-10.

2. Berkowitz RJ. Causes, treatment and prevention of early childhood caries: a microbiologic perspective. J Can Dent Assoc 2003; 69: 304-7.

3. Monroy PG. The age-1 dental visit and the dental home; a model for early childhood caries prevention. J Mich Dent Assoc 2007; 89: 32, 34-6.

4. Silva RAD, Nóia NB, Gonçalves LM, Pinho JRO, da Cruz MCF. Assessment of mothers' participation in a program of prevention and control of caries and periodontal diseases for infants. Rev Paul Pediatr 2013; 31: 83-9.

5. Nurko C, Skur P, Brown JP. Caries prevalence of children in an infant oral health educational program at a WIC clinic. J Dent Child (Chic) 2003; 70: 231-4.

6. Gomez SS, Weber AA. Effectiveness of a caries preventive program in pregnant women and new mothers on their offspring. Int J Paediatr Dent 2001; 11: 117-22.

7. Hallas D, Fernandez JB, Lim LJ, Catapano P, Dickson SK, Blouin KR, et al. OHEP: An oral health education program for mothers of newborns. J Pediatr Health Care 2015; 29: 181-90.

8. Lemos LVFM, Myaki SI, Walter LRdF, Zuanon ACC. Oral health promotion in early childhood: age of joining preventive program and behavioral aspects. Einstein (Sao Paulo) 2014; 12: 6-10.

9. Azevedo MS, Romano AR, dos Santos IdS, Cenci MS. Knowledge and beliefs concerning early childhood caries from mothers of children ages zero to 12 months. Pediatr Dent 2014; 36: 95E-9E.

10. Kahriman I, Karadeniz $H$, Tüzüner $T$, Kuşgöz $A$. An evaluation of the knowledge of pediatric nurses about the oral health status of newborns and pediatric oral health care. Clinical Nursing Studies 2017; 5: 53-8.

11. Albert D, Barracks SZ, Bruzelius E, Ward A. Impact of a web-based intervention on maternal caries transmission and prevention knowledge, and oral health attitudes. Matern Child Health J 2014; 18: 1765-71.

12. Gao X, Lo ECM, McGrath C, Ho SMY. Innovative interventions to promote positive dental health behaviors and prevent dental caries in preschool children: study protocol for a randomized controlled trial. Trials 2013; 14: 118. 
13. Aljafari A, Rice C, Gallagher JE, Hosey MT. An oral health education video game for high caries risk children: study protocol for a randomized controlled trial. Trials 2015; 16: 237.

14. Azevedo MS, Romano AR, Correa MB, Santos IdSd, Cenci MS. Evaluation of a feasible educational intervention in preventing early childhood caries. Braz Oral Res 2015; 29: S180683242015000100286.

15. Arora A, McNAB MA, Lewis MW, Hilton G, Blinkhorn AS, Schwarz E. 'I can't relate it to teeth': a qualitative approach to evaluate oral health education materials for preschool children in New South Wales, Australia. Int J Paediatr Dent 2012; 22: 302-9.

16. Saied-Moallemi Z, Virtanen J, Ghofranipour F, Murtomaa $H$. Influence of mothers' oral health knowledge and attitudes on their children's dental health. Eur Arch Paediatr Dent 2008; 9: 79-83.

17. Gurunathan D, Moses J, Arunachalam SK. Knowledge, Attitude, and Practice of Mothers regarding Oral Hygiene of Primary School children in Chennai, Tamil Nadu, India. Int J Clin Pediatr Dent 2018; 11: 338-43.
18. Makvandi Z, Karimi-Shahanjarini A, Faradmal J, Bashirian S. Evaluation of an oral health intervention among mothers of young children: A clustered randomized trial. J Res Health Sci 2015; 15: 88-93.

19. Hoeft KS, Barker JC, Shiboski S, Pantoja-Guzman E, Hiatt RA. Effectiveness evaluation of Contra Caries Oral Health Education Program for improving Spanish-speaking parents' preventive oral health knowledge and behaviors for their young children. Community Dent Oral Epidemiol 2016; 44: 564-76.

20. Kowash MB, Pinfield A, Smith J, Curzon ME. Effectiveness on oral health of a long-term health education programme for mothers with young children. Br Dent J 2000; 188: 201-5.

21. Weber-Gasparoni K, Warren JJ, Reeve J, Drake DR, Kramer KW, Marshall TA, et al. An effective psychoeducational intervention for early childhood caries prevention: part II. Pediatr Dent 2013; 35: 247-51. 